\title{
Islam Nusantara Rhetoric Among Intellectual Elites of Religious Organization
}

\author{
Dini Safitri \\ DIII Hubungan Masyarakat \\ Universitas Negeri Jakarta \\ Jakarta, Indonesia \\ mynameisdinisafitri@yahoo.com
}

\begin{abstract}
Nahdlatul Ulama (NU)'s rhetoric on Islam Nusantara, became a topic widely discussed among Islamic organization, especially in new media. NU's rhetoric faced few negation from another Islamic organization. one of them are Hizbut Tahrir Indonesia (HTI) who used their official website to offer counter rhetoric. This research aims to understand argumentation rhetoric of Islam Nusantara written at official website of NU and HTI. This research is using Toulmin's model of argumentation rhetoric and Bitzer's rhetoric situation theory. This research finds differences in speech act and Islam Nusantara rhetoric in new media which was caused by pedagogic literature and contestation of intellectual elites between NU and HTI.
\end{abstract}

Keywords: Rhetoric, New media, Islam Nusantara, Nahdlatul Ulama, Hizbut Tahrir Indonesia, Religious Organizations Political Strategy

\section{INTRODUCTION}

The emergence of new media had been used by Islamic organizations to disseminate their expressions and thoughts. One of them is Nahdlatul Ulama (NU), the largest Islamic Organization in Indonesia, who are using new media to spread Islam Nusantara, as an expression and product of their intellectual thought. The dissemination process is intensified since Islam Nusantara used as main theme for NU's national congress, which was held on August 1 to 5, 2015.

Prior to the congress, NU organized national conference of NU's clerics at the Istiqlal Mosque on June 14, 2015. The conference was opened by President Joko Widodo. At the opening speech, President Joko Widodo, openly expressed his support on the model of Islam Nusantara. Jokowi's support, earned many support as well as adversary. Affan wrote in the bbc.com (2015) that opponent parties interpret that Islam Nusantara supported Jokowi's, would make Muslims serve the foreign interests who wanted Muslims to be disintegrated. The speech was viewed as containing opinion that Indonesian Muslims do not require the application of Islamic law, did not criticize Israel which were previously regarded as a racist state for the Palestinian people, and the inclusion of many other practices that against the current majority of Islamic thinking.

Not long after the conference, the rhetoric of Islam Nusantara, again received criticism. The debate between the proponents and opponents of Islam Nusantara scattered in the new media. NU's intellectual elite as the originator of the idea of Islam Nusantara, continue to socialize its version of Islam Nusantara, especially on its official website. Contrary to NU's intellectual elite, the intellectual elite of Hizbut-Tahrir Indonesia (HTI), took a position against the rhetorical practice of Jokowi administration's version of Islam Nusantara, as it deemed controversial with the values of Islam that they understand. Therefore, the intellectual elite of HTI also made a number of rhetoric on why they reject Islam Nusantara published on the official website of HTI

Author selected new media as an object of study, because the new media has several advantages over other media. Author suggest that this topic is interesting to be examined since new media is an open space to express ideas and thought whether it is in form of proposition, opposition, or neutral. Participation in new media took form as an argument in new media. Interestingly, the exchange of arguments in new media were took place as a casual chat and did not require face-to-face interaction since it was established in a virtual chat room founded on a social network. The networking nature of new media opened new possibilities to develop a new model on argumentation exchanges based on new media's characteristics.

Author hopes this study will help to explain Islam Nusantara rhetoric arguments in new media, to create a model of Islam Nusantara rhetoric in the new media. This study is using Toulmin's argumentation rhetoric to analyze text on new media content. The use of this method is expected to enrich the text analysis methods, especially in texts containing elements of speech acts from Indonesian Islamic organizations in the new media. And to realize benefits from Muslims managed by a democratic government with Indonesian characteristic

\section{METHOD}

The paradigm of this study are interpretive. This approach was chosen, because it starts from the phenomenon that the object is built of a particular situation, which is internalized by individuals or particular social group. The method in this study is a rhetorical argument by Stephen Toulmin. This method was chosen for this study to examine 
the text in a column on the official website of NU and HTI. The number of text from the official website of NU are 40 and 4 from HTI's official website. This method is part of a text analysis method.

This study is limited to Islam Nusantara rhetoric on the official web NU and HTI, because there is competition (contestation) in the expression of the discourse of Islam Nusantara. Triangulation method in this research is done by comparing the information or data in a different way by using the method of observation and interviews. Observations made to the opinion text from NU's and HTI's intellectual elites. The interview was conducted using a structured interview to the informant from both sides.Author chose the authors of the majority of opinion from NU and HTI. In this study, author put the theory of pedagogy and counter hegemonic discourse.

\section{RESEARCH FINDINGS \& DISCUSSION}

Author see the differences in ground, warrant and claim (GWC) between text from NU and HTI in observing Islam Nusantara. On the Ground articulated by NU's text writers, the writers felt compelled to write because of Islam Nusantara themes is widely discussed, but many people misinterpret the intent of the Islam Nusantara discourse. Therefore, the authors of the texts which are the intellectual elites of NU, exposing Islam Nusantara by linking the themes of Islam Nusantara in NU's congress as initial campaign for the Islamic style of the Nusantara, accompanied by an explanation of Islam Nusantara as a theme of study that can be operationalized in the realm of academic and remove the misunderstandings about Islam Nusantara with exposure of cultural sovereignty strategy. Among the explanations of Islam Nusantara uncovered is the exposure that in the archipelago, scholars rarely hampered by demands to enforce Islamic law on those who embrace other religions and beliefs. This explanation, met with resistance from HTI, who are struggling to establish Islamic law in Indonesia.

Meanwhile grounded in the text of HTI, explains the background to why HTI must fight Islam Nusantara discourse. First, because the discourse of Islam Nusantara heralded by important people in Indonesia, namely the intellectual elite, MORA bureaucrats, politicians and a number of prominent Islamic organizations, but it has the interpretation contrary to Islam and must be rejected. Second, Islam Nusantara was built on the west paradigm, but made as if the original thinking Indonesia. Lighters early contestation of Islam Nusantara is, controversy the use of Java style in recitations of the Quran on the occasion of Isra 'and Mi'raj Prophet Muhammad SAW, May 17, 2015. Readings are to be assessed against the letter and the legal makhrojul recitation. Moreover, the discourse of Islam Nusantara is also supported by a strong fund, especially as the theme of study and research in the various educational institutions and government.

Warrant in the text NU, Islam Nusantara adapted to the context of the situation, in which it was written, demanding an explanation because there is a contestation of discourses Islam Nusantara. Among them are: (a) To enhance efforts Islam Nusantara fighters in the running of jurisprudence in accordance with the conditions of society archipelago; (b) urges the involvement of the thinkers of the Kiai, NU elders, scholars cadres NU, NU education practitioners, and the whole Neven and autonomous bodies to formulate education NU Islam Nusantara as the ideal concept of Islam which is applied in everyday life; (c) Explain to the rejecters of Islam Nusantara and counter that the bearer idiom: that should be followed from the Prophet is the moral a and not the expression of culture (not the same Arabization Islamization); Islam Nusantara support the experience of Islam in the expression of local culture; (d) Explain the historical facts of Islam Nusantara is a series of historical evidence gait Islam Nusantara by the WaliSongo, Ulama, and Pesantren in contributing force to achieve independence.

Warrant in the text HTI, shows that the concept of Islam Nusantara attributing to Walisongoa mask to cover the face of secular Islam Nusantara. The term Islam Nusantara is a reincarnation of the term "Islam Liberal", "IslamMorate", "Islam Indonesia" for various labels, was considered a failure, and no longer in demand in the Community. So that raised a new term, namely Islam Nusantara. Islam Nusantara almost similar to liberal Islam, propagated by the liberal Islamic groups in the world of higher education, with a tone of pride. But on the contrary, is not proud voice opinions enforcement of Islamic law. Therefore, HTI negating Islam Nusantara rhetoric.

Claim in the text NU, Islam Nusantara is Islam NU, relevant to the Homeland, where students act as pioneers of Islam Nusantara, to disseminate academic projects, culture, and civilization, boosted by standing a University of the NU with one name, College of Islam Nusantara, and always contextualized in the movement of history, thus giving birth to the system of science with character and social charactercountry, encouraging acts of emancipatory for the task of the intellectual, humanization, and social welfare, as well as the representation of rahmatanlil 'alamin. Meanwhile, the claim in the text of HTI, Islam Nusantara (IN) is an attempt to divide the people, arouse asabiyyah, and stem the caliphate. According to HTI, Islam is only one. Moreover, Islam is not for the Arabs, but the heavenly religions for all humans. Therefore, Islam claimed as rahmatanlil 'alamin.

Based on the comparison between NU and HTI claim against IN, discovered that they both use the word rahmatanlil 'alamin in a different perspective. In NU's perspective, Islam Nusantara is a representation of rahmatanlil 'alamin, because it uses the archipelago of jurisprudence that considers the benefit of the archipelago without having negated characteristics. Material Islam Nusantara, contextualized in the study of the history of Islam Nusantara, to be able to give birth to systems of knowledge, character and social character archipelago, thus encouraging actions for the task of emancipatory, humanization, and social welfare. Thus, Islam Nusantara as an academic project, culture and civilization, the representation rahmatanlil 'alamin. 
However, HTI may reject Islam Nusantara will be rahmatanlil 'alamin, because it can divide the people, raise asabiyyah (understand the fanaticism of the group), and stem the caliphate. HTI rejected the term Islam Nusantara for making Muslims into not one, because it has implications for split Muslims in a row, by way of breaking the terms of nationality, so the focus and attention of Indonesian Muslims, only the Muslim Nusantara alone, and disregard other Muslims that exist throughout the world. That is, a strategy the West wants is not the unification of Muslims in the world. In the absence of unity of the Muslims, the efforts to establish the Khilafah Islamiyahby automatically, will not occur. Due to the establishment of the Caliphate only happen, if the unification of Muslims in a leadership role (caliphate).

The results showed that the differences in perspectives, generate differences in speech acts and rhetoric in the way of new media. The worldview is shaped by the contextualization of discourse. Researchers interpret the contextualization of the discourse as the research findings, the pedagogical discourse and intellectual elite contestation. The intellectual elite pedagogical discourse, a theory developed by researchers from the theory of pedagogical discourse raised by Basil Bernstein. According to Bernstein, the discourse of pedagogy consists of classes, code and control. But in this study, researchers developed a discourse typical Indonesian pedagogy, namely: Discourse of Pedagogy intellectual elite.

NU step closer to making the classroom discourse, because it is supported by the power of money, media, and government. NU also has opened department of STAINU Islam Nusantara in Jakarta, which has been opened before NU to 33. Therefore, devices discourse more systematic NU class, have a curriculum, methods, theories and approaches explication is more intensive. Meanwhile, HTI manufactures rhetoric negation of Islam Nusantara because it considered it negates project HTI caliphate, when the discourse of Islam Nusantara was continuously produced without any explicit negation of HTI.
Contestation discourse of Islam Nusantara, represented by NU organizations and HTI, showed that the source of rhetoric between the two, comes from a different perspective on pedagogical discourse. The contestation occur, because The Islamic organizations bring the aspirations of religious understanding, religious activities, social and economic activities, as well as a political group. Pedagogical discourse, is the defense strategy of religious organizations, to has values and teachings, to the general public, as well as to expand their networks and movements, which are not limited to the intellectual elite.

\section{ACKNOWLEDGEMENT}

This paper based on my dissertation. My promotor was Prof. SasaDjuarsaSendjadja and co promotor was Prof. Ibnu Hamad.

\section{REFERENCES}

[1] Lunsford Andrea, Kirt H. Wilson dan R. Eberly (eds.) The SAGE Handbook of Rhetorical Studies. UK: Sage Publication Ltd, 2009.

[2] B. Bernstein, The structuring of pedagogical discourse. Class, codes and control, Volume 4. London: Routledge, 1990.

[3] Joko Tri Haryanto, "Relasi Agama dan Budaya dalam Hubungan Intern Umat Islam”. Jurnal SMaRT vol.1 no. 1, 2015, pp.41-54

[4] Dini Safitri,"Debat Retorika dalam Wacana Islam Nusantara”. Jurnal Commlinevol. VI No. 2, 2015, pp. 163-178

[5] Ibnu Hamad. Lebih Dekat dengan Analisis Wacana. MediatorVol.8 No.2, 2007,pp. 325-344

[6] Cristian Santibanez, "Metaphors and argumentation: The case of Chilean parliamentarian media participation". Journal od Pragmatics vol. 42 No. 4, 2010, pp.973-989

[7] Basuki Agus Suparno, Kontestasi Makna dan Dramatisme. Jurnal Ilmu Komunikasi vol. 8 No. 1, 2010, pp.27-38 